УДК 341.96:347.65

Юрій Валентинович Корнєєв, кандидат юридичних наук, дочент кафедри цчивільного права і прочесу Навчально-наукового юридичного інституту

Іванна Олегівна Коваль, студентка Навчально-наукового юридичного інституту Національний авіаційний університет

\title{
ОСОБЛИВОСТІ ПРАВОВОГО РЕГУЛЮВАННЯ СПАДКОВИХ ВІДНОСИН В МІЖНАРОДНОМУ ПРИВАТНОМУ ПРАВІ
}

Постановка проблеми. У міжнародному приватному праві важливе місце посідає інститут спадкування. Саме перехід прав та обов'язків спадкоємцю від спадкодавця за наявністю іноземного елемента $\epsilon$ причиною виникнення міжнародних спадкових відносин. Разом 3 тим виникає потреба як матеріально-правового, так і колізійного їх регулювання. Держави здійснюють правове регулювання спадкових відносин відповідно до національного законодавства, тому з'являються колізії між матеріально-правовими нормами різних держав, а це в свою чергу ускладнює правове регулювання міжнародних спадкових відносин.

Іноземний елемент в спадкових відносинах виявляється в тому, що спадкодавець, всі спадкоємці або деякі з них можуть бути громадянами різних держав, проживати в різних країнах, а також успадковуване майно може перебувати в різних державах. Вивчення та аналіз колізійних норм $€$ актуальним питанням, зокрема і для України, адже все частіше багато українців мігрують у інші країни і після смерті залишають спадщину, що вже нажита за час перебування за кордоном. Також актуальність вивчення колізійних питань підтверджується і тим, що заповітів складається дуже мало i іноді єдиним способом розподілу майна спадкодавця є спадкування за законом і тут постає питання застосування права якоїсь певної держави, адже коло спадкоємців за законом у правових системах різних держав відповідно різниться. Колізії законодавств у сфері спадкового права виникають тоді, коли окремі питання спадкування отримують неоднакове закріплення в праві різних країн.

Аналіз останніх досліджень і публікацій. Питання міжнародного спадкового права досліджували такі вчені, як О. В. Ракул, О. О. Кармаза, О. І. Нелін, О. Є. Кухарєв, Г. К. Дмитрієва, О. В. Альошина, а також багато інших, зокрема, іноземців.

Метою статті є аналіз колізійних норм в системі джерел правового регулювання спадкування за законом в міжнародному праві та їх значення для регулювання спадкових відносин з іноземним елементом, а також дослідження спадкового права зарубіжних країн.

Основні результати дослідження. Відповідно до ст. 1216 ЦК України спадкуванням є перехід прав та обов'язків (спадщини) від фізичної особи, яка померла (спадкодавця), до інших осіб (спадкоємців) [1].

У багатьох країнах норми, що регулюють спадкові відносини, знаходять своє відображення у цивільних кодексах. Наприклад, Німецьке Цивільне Уложення 1896 року містить книгу V «Спадкове право»; Цивільний кодекс Франції 1804 року містить відповідні положення стосовно спадкування у книзі III «Про різні способи набуття права власності», а саме Титул I «Про спадкування» та Титул II «Про дарування між живими та про заповіти».

Також, окрім титулів, кодексів та статутів, відносини спадкування можуть регулюватися спеціально прийнятими окремими законами (Іспанія). Неможливо не помітити, що в результаті рецепції римського права спадкове право, особливо в континентальній Європі, характеризується спільністю рис. Відмінним від такого порядку є система спадкування в країнах англоамериканської правової сім’ї, що насамперед пов'язано з провідною роллю судового прецеденту в цих державах [2] .

О. С. Кухарєв зазначає, що реалізація права спадкування дає змогу забезпечити перехід майна, що належало померлому, до інших осіб. Зміст права спадкування включає в себе не лише мож- 
Корнєєв Ю. В., Коваль І. О. Особливості правового регулювання спадкових відносин в міжнародному...

ливість набувати у власність майно спадкодавця (можливість спадкувати), а й можливість для власника майна розпорядитися ним на випадок смерті (можливість заповідати) [3, с. 256].

Іноземний елемент під час спадкування виявляється в тому, що за кордоном перебуває спадкове майно або спадкодавець чи спадкоємець (останні можуть мати громадянство іншої країни). У таких ситуаціях учасникам спадкових правовідносин, органам нотаріату та суду недостатньо знати матеріально-правові норми щодо спадкування, які діють в окремих країнах, їм необхідно також враховувати норми права, які застосовуються до спадкових відносин, ускладнених іноземним елементом.

Вважаємо, що через різноманітність правових систем в деяких випадках виникають колізії. Це пов'язано з тим, що різні країни можуть мати різну систему регулювання процесу спадкування. Регулювання спадкових відносин з іноземним елементом у міжнародному приватному праві здійснюється двома шляхами: застосуванням колізійної норми й норми національного матеріального права, до якої вона відсилається, та використанням норм, що містяться в міжнародних договорах держав. Таким чином, для врегулювання зазначених відносин застосовуються два методи регулювання: колізійний та матеріально-правовий.

Колізію в міжнародному спадкуванні слід визначити як таку правову ситуацію, в якій відносини по спадкуванню пов'язані з двома чи більше національними системами права, що здатні їх регулювати шляхом взаємодії [4, с. 189].

Колізійні норми у сфері міжнародного спадкування залежно від видів спадкування можна диференціювати, зокрема, на колізійні норми у сфері: спадкування за законом та спадкування за заповітом. Тому залежно від предмета спадкових відносин колізійні норми можемо розподілити на: колізійні норми щодо спадкування рухомого майна; колізійні норми щодо спадкування нерухомого майна; колізійні норми щодо спадкування інших майнових прав та обов'язків.

О. О. Кармаза зазначає, що у праві України для врегулювання спадкових відносин з іноземним елементом перевага надається колізійному методу, який $є$ методом непрямого регулювання зазначених відносин і полягає у виборі правопорядку, якщо врегулювати ці відносин «прагнуть» правопорядки двох або більше держав [5, с. 20].

Можна погодитися 3 думкою науковця, хоча Закон України «Про міжнародне приватне право» чітко не визначає, які саме колізійні норми необхідно застосовувати щодо спадкування за законом. У ст. 70 даного Закону лише зазначено, що спадкові відносини регулюються правом держави, у якій спадкодавець мав останнє місце проживання, якщо спадкодавцем не обрано в заповіті право держави, громадянином якої він був.

Можна вважати, що здатність особи до спадкування, черговість прийняття спадщини, розмір частки у спадщині будуть визначатися правом держави, де спадкодавець мав останнє місце проживання [6].

Для громадян України, які проживали за кордоном та померли і залишили спадщину у країні перебування, процедура спадкування такого майна спадкоємцями реулюється Положенням про порядок учинення нотаріальних дій в дипломатичних представництвах та консульських установах України [7], а також законодавства країни перебування за місцем відкриття спадщини, тобто останнього місця проживання померлого спадкодавця чи знаходження майна, яке входить до об'єктів спадщини.

Вибір правопорядку, тобто права держави, що буде застосовуватися до регулювання питань спадкування, є дуже важливим. Зазвичай, такий вибір права робиться, спираючись на принцип громадянства спадкодавця, або на принцип його місця постійного проживання.

В Україні спадкоємці за законом одержують право на спадкування почергово. Кожна наступна черга спадкоємців за законом одержує право на спадкування у разі відсутності спадкоємців попередньої черги, усунення їх від права на спадкування, неприйняття ними спадщини або відмови від іiї прийняття, крім випадків, встановлених статтею Цивільного кодексу України (ст. 1258 Цивільного кодексу України).

Черговість одержання спадкоємцями за законом права на спадкування може бути змінена нотаріально посвідченим договором зацікавлених спадкоємців, укладеним після відкриття спадщини.

У першу чергу право на спадкування за законом мають діти спадкодавця, у тому числі зачаті за життя спадкодавця та народжені після його смерті, той з подружжя, який його пережив, та батьки (ст. 1261 Цивільного кодексу України).

У другу чергу право на спадкування за законом мають рідні брати та сестри спадкодавця, його баба та дід як з боку батька, так і з боку матері (ст. 1262 Цивільного кодексу України). 
У третю чергу право на спадкування за законом мають рідні дядько та тітка спадкодавця (ст. 1263 Цивільного кодексу України).

У четверту чергу право на спадкування за законом мають особи, які проживали зі спадкодавцем однією сім'єю не менше п’яти років до часу відкриття спадщини (ст. 1264 Цивільного кодексу України).

У п’яту чергу право на спадкування за законом мають інші родичі спадкодавця до шостого ступеня споріднення включно, причому родичі ближчого ступеня споріднення усувають від права спадкування родичів подальшого ступеня споріднення (ст. 1265 Цивільного кодексу України) [1].

Закон України «Про міжнародне приватне право» чітко не визначає, які саме колізійні норми необхідно застосовувати щодо спадкування за законом. У ст. 70 даного Закону лише зазначено, що спадкові відносини регулюються правом держави, у якій спадкодавець мав останнє місце проживання, якщо спадкодавцем не обрано в заповіті право держави, громадянином якої він був [6].

Виходячи із змісту цієї норми, можна вважати, що здатність особи до спадкування, черговість прийняття спадщини, розмір частки у спадщині будуть визначатися правом держави, де спадкодавець мав останнє місце проживання. Проте у законодавстві України чітко не визначено, що необхідно розуміти під останнім місцем проживання

У Свропейських країнах спадкові правовідносини регулюються нормами кодифікованого законодавства, цивільними кодексами, окремими законами. Розглянемо приклади правого регулювання процесу спадкування в деяких країнах.

У Швейцарському цивільному кодексі законодавець виділяє три парантели (групи родичів): низхідні родичі, тобто пряма лінія споріднення; батьки спадкодавця і за певних умов їх низхідні; дід і баба спадкодавця та їх низхідні. Родичі, які належать до наступної парантели, закликаються до спадкування лише за умови відсутності родичів попередньої парантели. Особливе місце серед спадкоємців посідає той з подружжя, який пережив спадкодавця, його не включено до жодної із парантел, але він отримує спадщину разом із родичами тієї парантели, яка закликається до спадкування. Наприклад, якщо подружжя закликається до спадкування разом із родичами першої парантели, чоловік або дружина, які пережили, мають право на четверту частину спадщини; якщо з третьою на половину $[8$, с. 6$]$.

У Великій Британії, на відміну від країн континентальної Європи, той з подружжя, що пережив іншого, перебуває в особливому становищі. Воно має переважне право перед іншими спадкоємцями на предмети домашнього вжитку та особисті речі спадкодавця, фіксовану грошову суму, а також отримує в довічне користування половину спадкового майна, вільного від боргів - за наявності дітей спадкодавця, і все майно - за їх відсутності [9, с.483].

Окрім спадкування за законом, існує і спадкування за заповітом, що в Україні регламентується нормами глави 85 Цивільного кодексу України. У Швейцарії, Великій Британії, більшості штатів США здатність до складання заповіту виникає з 18 років, у Німеччині право на складання заповіту надано і 16-річним особам (Німецьке цивільне положення). У Франції, окрім повнолітніх осіб, заповіт можуть складати і неповнолітні, які досягли 16-ти років, але лише щодо половини належного їм майна.

У країнах континентальної Європи передбачена обов'язкова умова дійсності заповіту - письмовий власноручний заповіт, тобто той, що заповідач склав власноручно з дотриманням встановлених законодавством вимог, заповіт у формі публічного акта, таємні заповіти та спеціальні заповіти. Наприклад, законодавством Великої Британії передбачено, що заповіт має бути підписаний заповідачем і його волевиявлення повинно бути посвідчено двома свідками [8, с. 7].

Висновки. Дослідивши європейські правові системи спадкування, можна дійти висновку, що у даних країнах воно розглядається як універсальне правонаступництво, згідно з яким права і обов'язки спадкодавця переходять безпосередньо до спадкоємців.

Аналізуючи розвиток Українського спадкового права, можна сказати, що простежується розширення кордонів свободи заповіту, розширення кола спадкоємців за законом, а в західних країнах простежується, навпаки, тенденція до звуження, тим самим даючи змогу появи права на відумерлу спадщину. Таким чином, розвиток українського спадкового права та спадкового права західних країн рухається в протилежних напрямках.

Колізійні норми в системі джерел правового регулювання спадкування в міжнародному праві відіграють дуже важливе значення. Це зумовлено тим, що будь-яка фізична особа незалежно 
від різних чинників рано чи пізно стає суб'єктом спадкових відносин. У будь-якому разі після смерті громадянина України за кордоном або якщо його майно чи майнові права знаходяться за межами України, виникає низка правових проблем, серед яких важливе місце відводиться питанням правового регулювання спадкових відносин. Хоча українське міжнародно-правове законодавство і регулює певні спадкові відносини, однак тих норм, що зараз $є$ у наявності, не достатньо для повного і всебічного врегулювання усіх питань, що можуть виникнути у спадкових правовідносинах з іноземним елементом. Вважаємо доцільним взяти до уваги практику Європи щодо даних питань та виробити на основі цього власну систему правового регулювання спадкових відносин, яка б могла ефективно працювати в умовах сьогодення.

\section{Список використаних джерел}

1. Цивільний кодекс України : Закон України від 16.01.2003 № 435-IV // Відомості Верховної Ради. - 2003. №№ 40-44. - Ст. 356.

2. Р Ракул О. В. Спадкове право України та європейських країн: деякі основні відмінності [Електронний ресурс]. Режим доступу : http://www.spilnota.org.ua/ru/article/id-1204/

3. Кухарєв О. Є. Спадкове право України : навч. посібник / О. Є. Кухарєв. - К. : Алерта, 2013. - 328 с.

4. Міжнародне приватне право : навч. посібник / За ред. В. М. Гайворонського, В. П. Жушмана. - К. : Юрінком Інтер, 2005. - $368 \mathrm{c}$.

5. Кармаза О. О. Спадкування у сучасному міжнародному праві : автореф. дис. ... канд. юрид. наук : 12.00.03.К., 2006. $-18 \mathrm{c}$.

6. Про міжнародне приватне право : Закон України від 23.06.2005 № 2709-IV // Відомості Верховної Ради України. -2005 . - № 32. - Ст. 422.

7. Положення про порядок вчинення нотаріальних дій в консульських установах та диплломатичних представництвах: затв. наказом Міністерства юстиції України, Міністерства закордонних справ України від 27.12.2004 p. № 142/5/310. URL: http://zakon.rada.gov.ua/laws/show/z1649-04.

8. Нелін O. I. Історико-правовий аналіз спадкового права України та країн континентальної Європи, Великої Британії і США // Юридична Україна: Щомісячний правовий часопис. - 2013. - № 3. - С. 4-8.

9. Международное частное право : учеб. / Под ред. Г.К. Дмитриевой. - М., 2001. - 656 с.

\section{References}

1. Tsyvilnyi kodeks Ukrainy: Zakon Ukrainy vid 16.01.2003 № 435-IV // Vidomosti Verkhovnoi Rady. - 2003. №№ 40-44. - St. 356.

2. Rakul O. V. Spadkove pravo Ukrainy ta yevropeiskykh krain: deiaki osnovni vidminnosti. [Elektronnyi resurs]. Rezhym dostupu : http://www.spilnota.org.ua/ru/article/id-1204/

3. Kukhariev O. Ye. Spadkove pravo Ukrainy: Navch. posibnyk / O. Ye. Kukhariev. - K. : Alerta, 2013. - $328 \mathrm{~s}$.

4. Mizhnarodne pryvatne pravo: Navch. posibnyk / Za red. V.M. Haivoronskoho, V.P. Zhushmana. - K. : Yurinkom Inter, 2005. $-368 \mathrm{~s}$.

5. Karmaza O. O. Spadkuvannia u suchasnomu mizhnarodnomu pravi: avtoref. dys. na zdobuttia nauk. stupenia kand. yuryd. nauk: spets. 12.00 .03 - tsyvilne pravo; tsyvilnyi protses; simeine pravo; mizhnarodne pryvatne pravo. K., 2006. $-18 \mathrm{~s}$.

6. Pro mizhnarodne pryvatne pravo: Zakon Ukrainy vid 23.06.2005 № 2709-IV // Vidomosti Verkhovnoi Rady. 2005. - № 32. - St. 422.

7. Polozhennia pro poriadok vchynennia notarialnykh dii $\mathrm{v}$ konsulskykh ustanovakh ta dypllomatychnykh predstavnytstvakh: zatv. Nakazom Ministerstva yustytsii Ukrainy, Ministerstva zakordonnykh sprav Ukrainy vid 27.12.2004 r. № 142/5/310. URL: http://zakon.rada.gov.ua/laws/show/z1649-04.

8. Nelin O. I. Istoryko-pravovyi analiz spadkovoho prava Ukrainy ta krain kontynentalnoi Yevropy, Velykoi Brytanii i SShA // Yurydychna Ukraina: Shchomisiachnyi pravovyi chasopys. - 2013. - № 3. - S. 4-8.

9. Mezhdunarodnoe chastnoe pravo: Uchebnik / Pod red. G.K. Dmitrievoj. - PBOYuL Grizhenko E. M., 2001. - 656 s.

\section{Корнсєв Ю. В., Коваль І. О. Особливості правового регулювання спадкових відносин в міжнародному приватному праві}

Досліджується місце колізійних норм в системі джерел правового регулювання спадкування за законом в міжнародному приватному праві, їх значення для регулювання спадкових відносин з іноземним елементом. Розглянуто поняття іноземного елемента у спадкових відносинах. Розглянуто правове регулювання спадкових відносин в різних країнах. Висвітлений процес спадкування за українськими законодавством та зроблений порівняльний аналіз з законодавством деяких країн. Розглянуті проблеми правового регулювання спадкових відносин з інозем- 
ним елементом в Україні та наданий можливий варіант подолання даної проблеми.

Ключові слова: спадкування, спадкодавець, спадкоємець, спадкування за законом, спадкування за заповітом, колізія, іноземний елемент, міжнародне приватне право, спадкові правовідносини.

Korniew Y. V., Koval I. O. Features of legal regulation of hereditary relations in international private law In many countries, the rules governing inheritance relations are reflected in the Civil Codes. For example, the German Civil Code of 1896 contains a book V «Ancestral Law»; The French Civil Code of 1804 contains the relevant provisions concerning inheritance in Book III «On Different Methods of Acquiring the Right to Own Property», namely Titles I «On inheritance» and Title II «On donation between living and bequeathed».

Also, in addition to titles, codes and statutes, the inheritance relationship may be governed by specially adopted separate laws (Spain). It is not impossible not to notice that, as a result of the reception of Roman law inheritance law, especially in continental Europe, is characterized by the common rice. The system of inheritance in the countries of the Anglo-American legal family is different from this order, which is primarily due to the leading role of the judicial precedent in these states.

A foreign element during inheritance is manifested in the fact that abroad there is an inherited property or a successor or heir (the latter may have the citizenship of another country). In such situations, the parties to the hereditary legal relationship, the notary and the court do not have enough knowledge of the material rules of inheritance that operate in individual countries, they must also take into account the rules of law applicable to hereditary relationships, complicated by a foreign element.

In the law of Ukraine for the regulation of hereditary relations with a foreign element, the preference is given to the collisional method, which is a method of indirect regulation of these relations and consists in choosing the rule of law, if they regulate these relations, «seek» the rule of law of two or more states

The place of conflict rules in the system of sources of legal regulation of inheritance by law in private international law is investigated, their importance for the regulation of hereditary relations with a foreign element. The legal regulation of hereditary relations in different countries is considered. The process of inheritance under Ukrainian legislation is highlighted and a comparative analysis has been made with the legislation of some countries. The problems of legal regulation of hereditary relations with a foreign element in Ukraine are considered and a possible variant of overcoming this problem is given.

Key words: inheritance, successor, heir, inheritance by law, inheritance by will, conflict, foreign element, international private law, inheritance legal relationship.

DOI: 10.33.66.3/2524-017X-2019-10-308-312

УДК 342.7

Тетяна Анатолївна Костецька, стариий науковий співробітник Інституту держави і права ім. В. М. Корецького

НАН Украӥни, кандидат юридичних наук, доиент

\section{ДО ПИТАННЯ ПРО ДЕРЖАВНИЙ КОНТРОЛЬ ЗА ДОТРИМАННЯМ ІНФОРМАЦЙННОГО ЗАКОНОДАВСТВА: ПОНЯТТЯ, ОКРЕМІ ВИДИ І ФОРМИ}

Постановка проблеми. Незважаючи на наявність значного відповідного потенціалу, нинішній стан розвитку України характеризується, зокрема, існуванням суттєвих проблем з формування та реалізації ефективної державної політики у сфері розвитку інформаційного суспільства, в якій, як визначено разом із іншими чинниками, відсутній план дій щодо реалізації національної стратегії щодо такого розвитку; не подолано цифрову нерівність у доступі громадян України до електронних комунікацій та інформаційних ресурсів, повільно зростає рівень комп'ютерної грамотності населення; має місце низький рівень впровадження та використання можливостей інформаційнокомунікаційних технологій у багатьох сферах [1 ].

Зростаюча роль у комплексному вирішенні поставлених на державному рівні завдань, виходячи із національних інтересів та забезпечуючи баланс інтересів особистості, держави, суспільства зага- 